\title{
Identification of extracellular enzyme producing thermophilic bacilli from Balcova (Agamemnon) geothermal site by ITS rDNA RFLP
}

\author{
E. Yavuz ${ }^{1}$, H. Gunes ${ }^{2}$, S. Harsa ${ }^{1}$ and A.F. Yenidunya ${ }^{2}$ \\ ${ }^{1}$ Biotechnology and Bioengineering Programme, and ${ }^{2}$ Department of Biology, Science Faculty, Izmir Institute of Technology, Gulbahce, \\ Izmir, Turkey
}

2003/1079: received 25 November 2003, revised 17 May 2004 and accepted 18 May 2004

\begin{abstract}
E. YAVUZ, H. GUNES, S. HARSA AND A.F. YENIDUNYA. 2004.
\end{abstract}

Aims: Molecular characterization of extracellular enzyme producing thermophilic bacilli from Balcova geothermal site.

Methods and Results: Three types of geothermal samples were collected: mud, re-injection water, and samples from uncontrolled hydrothermal vents. Isolates grown at $55^{\circ} \mathrm{C}$ in culture media prepared in sterilized re-injection water, were screened for extracellular enzyme activity by using eight different substrates: casein, carboxymethylcellulose, pectin, polygalacturonic acid (PGA), soluble starch, Tween 20 and 80, and xylan. In total, 109 thermoaerophilic isolates were selected. All of the isolates could hydrolyse Tween 20 (100\%) but not Tween 80 . Soluble starch was hydrolysed by $96 \%$, casein by $55 \%$, xylan and carboxymethylcellulose by $9 \%$, and pectin and PGA by $2 \%$ of the isolates. The isolates were grouped into 14 different homology groups by the restriction pattern analysis of 16S-internal transcribed spacer (ITS) rDNA RFLP. Each of the RFLP groups was also studied by 16S rRNA gene partial sequence analysis. Plasmid DNA profiles revealed that 15 of the isolated strains contained small plasmid DNA molecules ranging in size from 12000 to $35000 \mathrm{bp}$.

Conclusions: Combined analysis of 16S-ITS rDNA RFLP and 16S rRNA gene partial sequence results indicated the presence of novel or existing species of Anoxybacillus (nine species) and Geobacillus (three species).

Significance and Impact of the Study: In this study 16S-ITS rDNA RFLP was applied for the first time to differentiate thermophilic bacilli. It was also the first study on thermophilic bacilli of Balcova geothermal site.

Keywords: 16S-ITS rDNA RFLP, extracellular enzyme screening, geothermal, similarity analysis, thermophilic bacilli.

\section{INTRODUCTION}

Balcova geothermal hot springs, situated at the west end of Izmir, are known to be the first geothermal hospital in history, dating back as far as BC 1200. In Homeros' Iliada, for example, it had been written that after the Troian War, Agamemnon had been to Izmir, and his soldiers healed their wounds in Balcova hot springs, and that people of Balcova

Correspondence to: A. Fazil Yenidunya, Department of Biology, Science Faculty, 35430 Gulbahce, Izmir, Turkey (e-mail: afazilyenidunya@iyte.edu.tr). had then named the geothermal hot springs after Agamemnon. Today, the hot springs serve as a modern geothermal hospital called Balcova Physical Therapy and Rehabilitation Centre. It also serves as the largest geothermal heating system in Turkey.

The genus Bacillus has been described as a large and heterogeneous collection of aerobic and facultatively anaerobic, rod-shaped, Gram-positive to Gram variable, endospore-forming bacteria (Slepecky and Hemphill 1991; Goto et al. 2000). Identification of these bacteria has been imprecise by traditional biochemical techniques (Flint et al. 
2001). A recent taxonomic study has included aerobic thermophilic bacilli under a new genus, Geobacillus (Nazina et al. 2001). Many kinds of species with thermophilic, psychrophilic, acidophilic, alkalophilic and halophilic properties have been included in this genus (Nazina et al. 2001). The genus Anoxybacillus has also been separated from Bacillus (Pikuta et al. 2000, 2003). It contains three aerotolerant anaerobe species, Anoxybacillus flavithermus DSM $2641^{\mathrm{T}}$, Anoxybacillus pushchinensis DSM $12423^{\mathrm{T}}$ (Pikuta et al. 2000), and Anoxybacillus gonensis NCIMB 13933 (Belduz et al. 2003).

Thermophilic bacilli show optimal growth at temperatures ranging from 45 to $70^{\circ} \mathrm{C}$ (Rainey et al. 1994; Maugeri et al. 2001) and can be isolated from both thermophilic and mesophilic environments (Marteinsson et al. 1996). The importance of these bacteria has increased as the source of thermostable enzymes: amylases, cellulases, glucose-isomerases, lipases, proteases, pullulanases, xylanases and DNA restriction endonucleases (Rainey et al. 1994; Demirjian et al. 2001; Maugeri et al. 2001). Thermal stability enables these enzymes to be active in the presence of chemical denaturants and to resist harsh process conditions (Kristjansson 1989; Adams and Kelly 1998; Aguilar et al. 1998). High temperature in turn influences the availability and solubility of organic compounds by lowering the viscosity and thereby increasing their diffusion coefficients (Niehaus et al. 1999). These features are thus mutually beneficial for the industry in diverse areas (Haki and Rakshit 2003).

In the present study, a molecular identification study was carried out on the extracellular enzyme producing thermophilic bacilli in Balcova geothermal site.

\section{MATERIALS AND METHODS}

\section{Reference strains}

Geobacillus stearothermophilus (CECT 43, the type strain of G. stearothermophilus), G. stearothermophilus (CECT 47), G. stearothermophilus (CECT 48), G. stearothermophilus (CECT 49) and G. kaustophilus (CECT 4264) were obtained from The Spanish Type Culture Collection (CECT). Geobacillus thermoglucosidasius (NRRL 1407) was obtained from Agricultural Research Service Culture Collection (ARS/NRRL, Peoria, IL, USA).

\section{Sampling and isolation}

In total eight samples were collected from Balcova geothermal site. One of the samples was from injection water $\left(90^{\circ} \mathrm{C}\right.$, $\mathrm{pH} 8.0$ ), which was just pumped out of the geothermal reservoir and before fed into the Balcova district heating system. Another water sample was collected at the returning point of the heating system (re-injection water, $65^{\circ} \mathrm{C}, \mathrm{pH} 8$ 5).
Two of the samples were taken from uncontrolled thermal vents $\left(70\right.$ and $\left.75^{\circ} \mathrm{C}, \mathrm{pH} 8 \cdot 5-9 \cdot 0\right)$. The water samples were collected and stored in thermos flasks during transportation, which lasted for $1 \mathrm{~h}$. Four of the samples were from Balcova Physical Therapy and Rehabilitation Centre: two soil samples ( $\mathrm{pH} 8$ and 9$)$; and two water samples $\left(60^{\circ} \mathrm{C}-65^{\circ} \mathrm{C}, \mathrm{pH} 8 \cdot 5\right)$.

Both dilution plate and enrichment methods were used for the isolation of bacteria from water samples (Holt and Krieg 1994). Culture media $\left(1 \mathrm{~g} \mathrm{l}^{-1}\right.$ yeast extract, $1 \mathrm{~g} \mathrm{l}^{-1}$ glucose and $15 \mathrm{~g} \mathrm{l}^{-1}$ agar) used for the isolation were prepared in reinjection water. Reference and the isolated strains were suspended in isolation broth containing $20 \%$ glycerol and stored at $-80^{\circ} \mathrm{C}$.

\section{Phenotypic studies}

Isolates were first Gram stained and examined under the light microscopy. Sporulation was examined under the phasecontrast microscope (Olympus, Tokyo, Japan). Catalase and oxidase tests were performed. The isolates were then subjected to some physiological tests on nutrient agar plates for 1-3 days: growth at $37,45,65$ and $70^{\circ} \mathrm{C}$; in the presence of $0 \cdot 5,1,3$ and $6 \%(\mathrm{w} / \mathrm{v}) \mathrm{NaCl}$ at $55^{\circ} \mathrm{C}$; at $\mathrm{pH} 8,9$ and 10 at $55^{\circ} \mathrm{C}$. Isolates were also screened for the extracellular enzyme activity at $55^{\circ} \mathrm{C}$ by following the protocols described in the references below: proteolytic activity (Priest et al. 1988); amylolytic, cellulolytic, and xylanolytic activities (Bragger et al. 1989); pectinolytic activity (Kobayashi et al. 1999); and lipolytic activity (Haba et al. 2000).

\section{Genomic DNA extraction and amplification}

Genomic DNA was extracted according to Ausubel et al. (1994). Amplification of the DNA fragments containing $16 \mathrm{~S}$ rRNA gene and internal transcribed spacer (ITS) sequences was performed as described in Akbalik et al. (2004).

\section{Plasmid DNA extraction and analysis}

Bacteria were streaked from frozen glycerol stocks onto nutrient agar plates and were then incubated overnight at $55^{\circ} \mathrm{C}$. The cells were scraped and suspended in $1.5 \mathrm{ml}$ sterile water. The method of Sullivan and Klaenhammer (1993) was followed for the extraction of small plasmid DNA. After digesting with $H a e I I I$ restriction enzyme, restriction products were resolved in a $1 \%$ agarose gel and the size of the plasmid DNA molecules were calculated in a gel documentation system (Vilber-Lourmat, Torcy, France).

\section{S-ITS rDNA RFLP analysis}

16S-ITS rDNA RFLP analysis was performed as described in Akbalik et al. (2004). RFLP fragmentation patterns were 
normalized against a DNA size marker (GeneRuler; Fermentas, Vilnius, Lithuania) and were then analysed with $15 \%$ homology coefficient in a Bio-1D++ software (VilberLourmat). The similarity between the strains was determined automatically by specifying the formula of Nei and $\mathrm{Li}$, and clustering was performed by the un-weighted pair group method with arithmetic averages, UPGMA (VilberLourmat).

\section{Partial DNA sequencing on the 16S rRNA gene}

One representative isolate which was randomly picked among the members of each of the 16S-ITS RFLP homology groups (Table 1), was used for 16S rRNA gene partial sequence analysis. Thermo Sequenase Cy5.5 Dye Termintor Cycle Sequencing Kit (Amersham Biosciences, Buckinghamshire, UK) and 5'-AGAGTTTGATCCTGGCTCAG-3' forward primer (Jensen et al. 1993) were used for the reactions. Sequencing results were obtained in a SEQ $4 \times 4$ personal sequencer system (Amersham Biosciences, Buckinghamshire, UK). So far the following 12 accession numbers were obtained from GenBank: AY534880, AY534881, AY554161, AY554162, AY554163, AY558811, AY558812, AY558813, AY558814, AY559837, AY601781 and AY601782 for the isolates V90, M6.p1, R30, R32, R72, M14, R21, R40·1, R79, $\mathrm{V} 1,75 \mathrm{~B}$, and $\mathrm{R} 76$, respectively (Table 1 ).

\section{RESULTS}

In total, 109 isolates were obtained and $45 \%$ of these were from the uncontrolled thermal vent, $31 \%$ were from the reinjection water, and $24 \%$ were from the mud samples. The sources of the isolates were indicated in their names (Table 1): strain names starting with ' $\mathrm{M}$ ' specified the mud isolates, with ' $R$ ' the re-injection water isolates, and with ' $V$ ' the uncontrolled thermal vent isolates. The isolated strains were differentiated into 14 distinct RFLP homology groups by $16 \mathrm{~S}-\mathrm{ITS}$ rDNA restriction pattern analysis (Table 1 ).

\section{Phenotypic characterization}

Morphology. All of the isolated strains were Gram-positive, rod-shaped, catalase and oxidase positive, and endospore-forming bacteria. The positions of the spores in the cells were subterminal or terminal.

Physiological properties. All of the isolates grew at 45 and $65^{\circ} \mathrm{C}$, at 0.5 and $1 \%(\mathrm{w} / \mathrm{v}) \mathrm{NaCl}$, and at $\mathrm{pH} 8$. None of the isolates grew at $6 \%(\mathrm{w} / \mathrm{v}) \mathrm{NaCl}$. Only $12 \%$ of the isolates did not grow at $37^{\circ} \mathrm{C}$. These results indicated that majority of the strains were moderate or facultative thermophiles (Huges and Williams 1977). Remaining of the phenotypic characterization results were listed in Table 1.
Most of the isolates displayed more than one extracellular enzyme activity (Table 1). One prominent feature of the extracellular enzyme screening results was that all the isolates could hydrolyse Tween 20 and that none of the isolates hydrolysed Tween 80 . Pectin and polygalacturonic acid (PGA) hydrolysis was found to be the least frequent activity (Table 1).

\section{S-ITS rDNA RFLP analysis}

One hundred and nine isolated, and six reference strains were identified on the basis of their 16S-ITS rDNA restriction profiles. Two frequent cutter endonucleases, TaqI and Hae III were used for the restriction reactions. Digestion products of each of the enzymes were resolved in a preparative agarose gel. Isolates producing identical restriction profiles were classified into specific groups (RFLP homology groups, Table 1). Restriction products representing these groups were then electrophoresed together with those of six reference strains. After this, similarity analyses were performed on the group patterns at 15\% homology coefficient. RFLP homology groups obtained with each of the enzymes were combined and interpreted.

Taq/ digestion. Seventeen restriction patterns, 11 isolates and six reference strains, were used for the evaluation of TaqI digestion profiles. TaqI digestion resulted in 14 distinct homology groups (Fig. 1). Four of these were formed by the reference strains. The RFLP homology TH1 (A, Fig. 1) was clustered with the reference strain $G$. stearothermophilus (CECT 43). This reference strain seemed to have a different restriction profile from those of the other G. stearothermophilus strains CECT 47, 48, and 49 (A, Fig. 1). The most prominent feature of the $T a q \mathrm{I}$ dendrogram was that almost all of the isolates were included into a distinct and large cluster (B, Fig. 1) which consisted of two subclusters. One of these subclusters contained the homology groups T2, T4, T5 and TH6. In this clustering, the closest groups appeared to be 55 and TH6. The other subcluster contained groups T1, T3, TH2, TH3, TH4 and TH5. It included three closest homology groups (T1, T3 and TH2).

Haelll digestion. Fifteen restriction patterns, nine isolates and six reference strains, were used for the evaluation of HaeIII digestion profiles. Analysis of the HaeIII restriction patterns revealed 12 distinct homology groups (Fig. 2). Four of the groups were formed by the reference strains. Three strains of G. stearothermophilus (CECT 47, 48, and 49) formed one homology group. G. stearothermophilus (CECT 43) was however clustered together with homology group TH1 (A, Fig. 2). G. kaustophilus was the closest strain to this cluster. However, this time G. thermoglucosidasius (NRRL 1407) was located much closely to the isolate groups. 


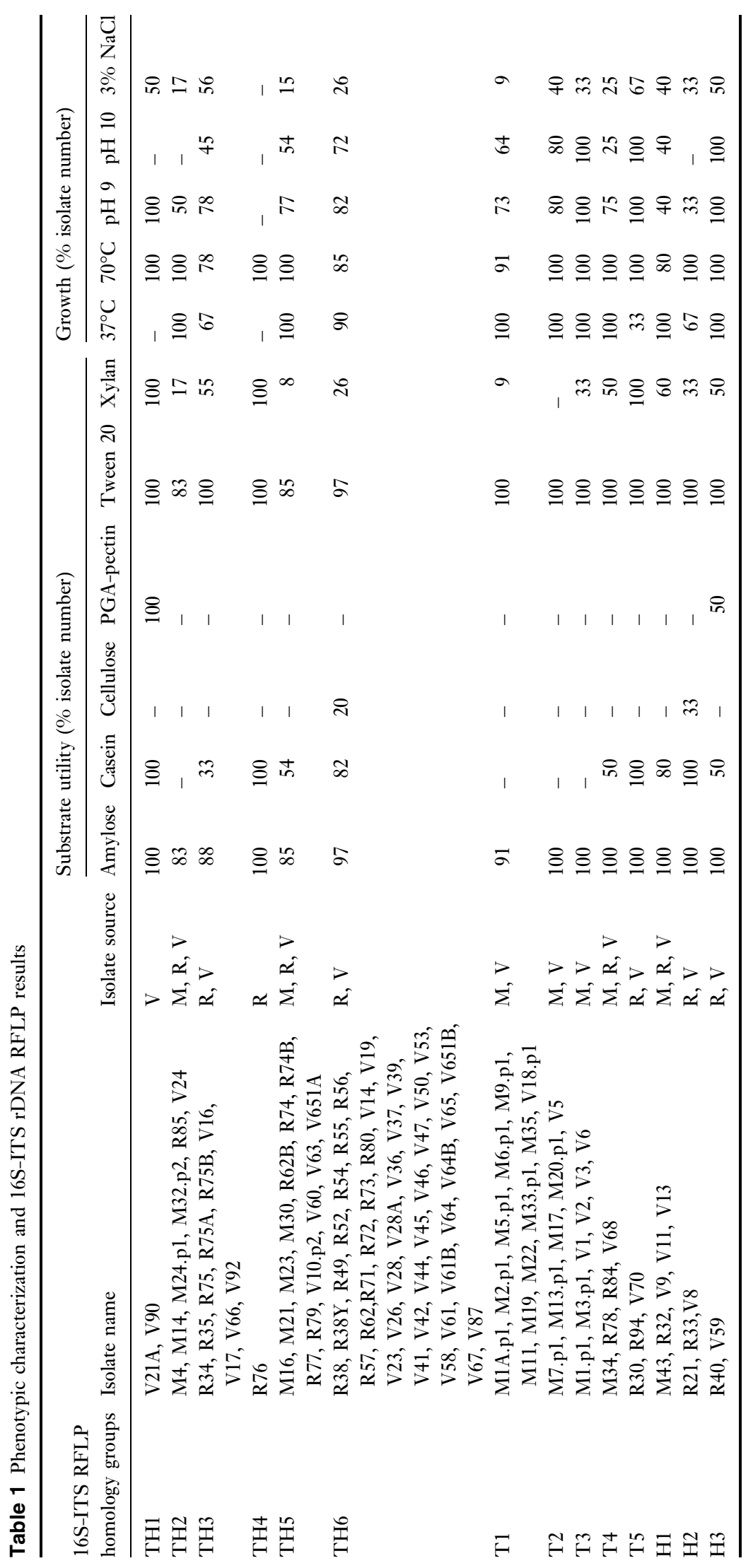




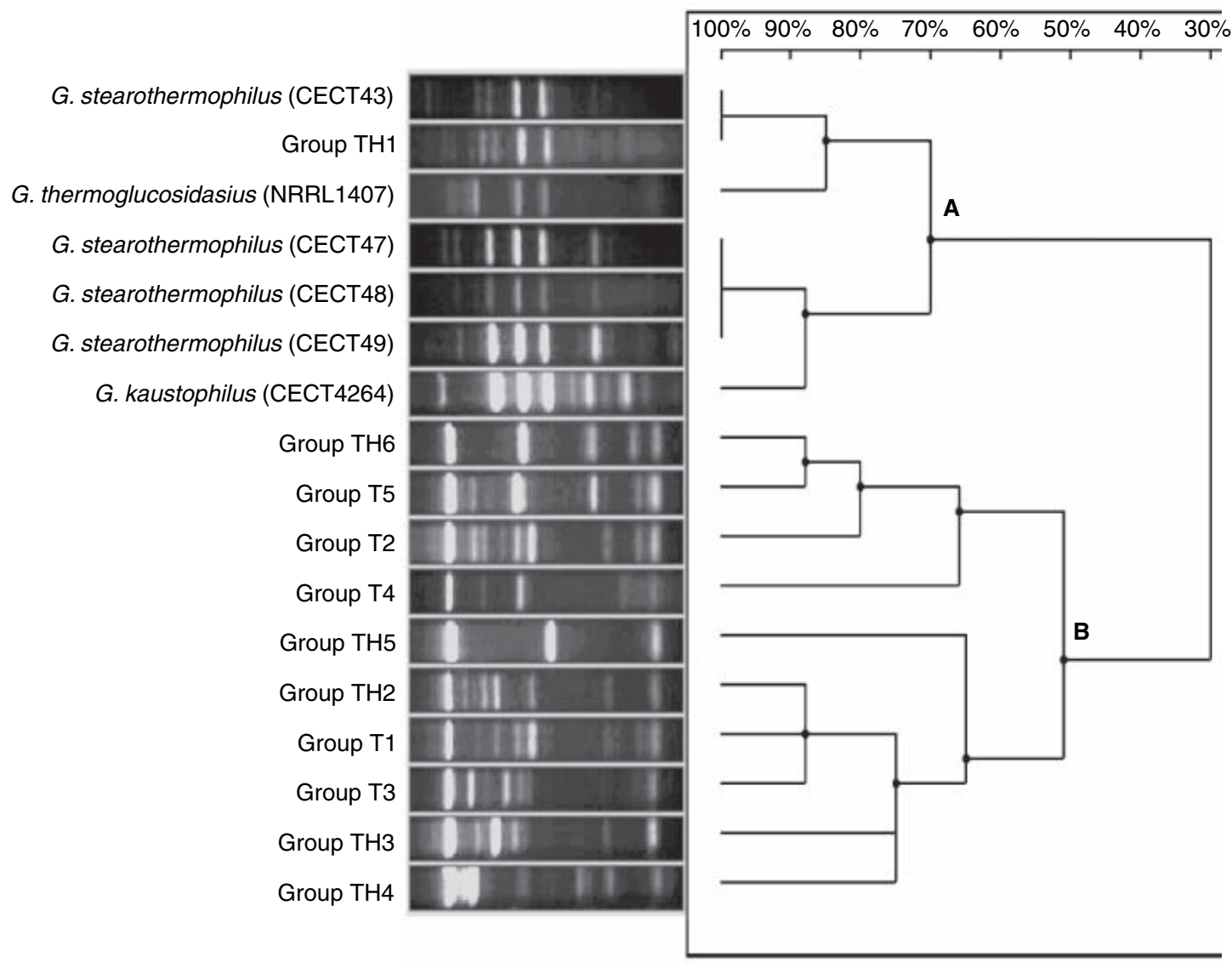

Fig. 1 Dendrogram showing the 16S-ITS rDNA RFLP homology groups obtained with TaqI restriction enzyme. Restriction patterns of each of the homology groups were normalized against a DNA size marker (1 kb DNA ladder; Fermentas), and analysed with $15 \%$ homology coefficient in a computer programme (Bio-1 D++; Vilber-Lourmat). The name of the homology groups and of reference strains were indicated (left). A and B indicate the two main clusters

Remaining of the isolates formed two distinct clusters: (i) $\mathrm{H} 2$ and TH4 (C, Fig. 2); (ii) H1 which was clustered with G. thermoglucosidasius (NRRL 1407), H3, TH3, TH5 and TH6 (B, Fig. 1).

\section{Combined analysis of the RFLP homology} groups. Isolated strains could be differentiated into 14 distinct homology groups after combining the results of the dendrograms generated by $T a q \mathrm{I}$ and HaeIII restriction enzyme profiles (Table 1). Seventy of the isolates were differentiated into six identical homology groups by both enzymes, and these were designated as TH groups (TH1TH6). The number of the isolates contained within these groups varied. TH4 for example was represented by only one isolate (R76) while the largest group, TH6, contained 39 isolates. The groups that could be identified by only one of the restriction enzymes were designated as either $\mathrm{T}(\mathrm{Taq} \mathrm{I}$ specific groups) or $\mathrm{H}$ (HaeIII specific groups). Five $\mathrm{T}$ groups (T1, T2, T3, T4 and T5) and three $\mathrm{H}$ groups $(\mathrm{H} 1$, $\mathrm{H} 2$, and $\mathrm{H} 3$ ) were thus identified.

\section{Partial sequence analysis of 16S rRNA gene}

BLAST analysis of the sequencing results revealed the following 16S rRNA gene's partial sequence features of the representative isolates. Among the isolate groups the highest sequence similarity $(88 \%)$ was found between TH2 (isolate M14) and T3 (isolate V1). The closest species to these groups was A. flavithermus (AF482430, with 94\% similarity between nucleotides 101-452). Seven more homology groups also showed quite high sequence similarity, ranging from 83 to $93 \%$, to A. flavithermus (accession no: AJ586360): groups H1 (isolate R32), H3 (isolate R40), group T1 (isolate M6.p1), and TH3 (isolate 75B); and to A. flavithermus (DSM 2641): groups TH5 (isolate R79), T5 (isolate R30), and TH6 (isolate R72). Groups H2 (isolate R21) and TH1 (isolate V90) displayed $86 \%$ sequence similarity to those of both $G$. thermoleovorans (accession no: ATCC43513) and G. thermoleovorans (BGSG 9A21), respectively. The isolate 76 representing the TH4 group sequence displayed 91\% similarity to G. subterraneus (accession no: AF276308). For 


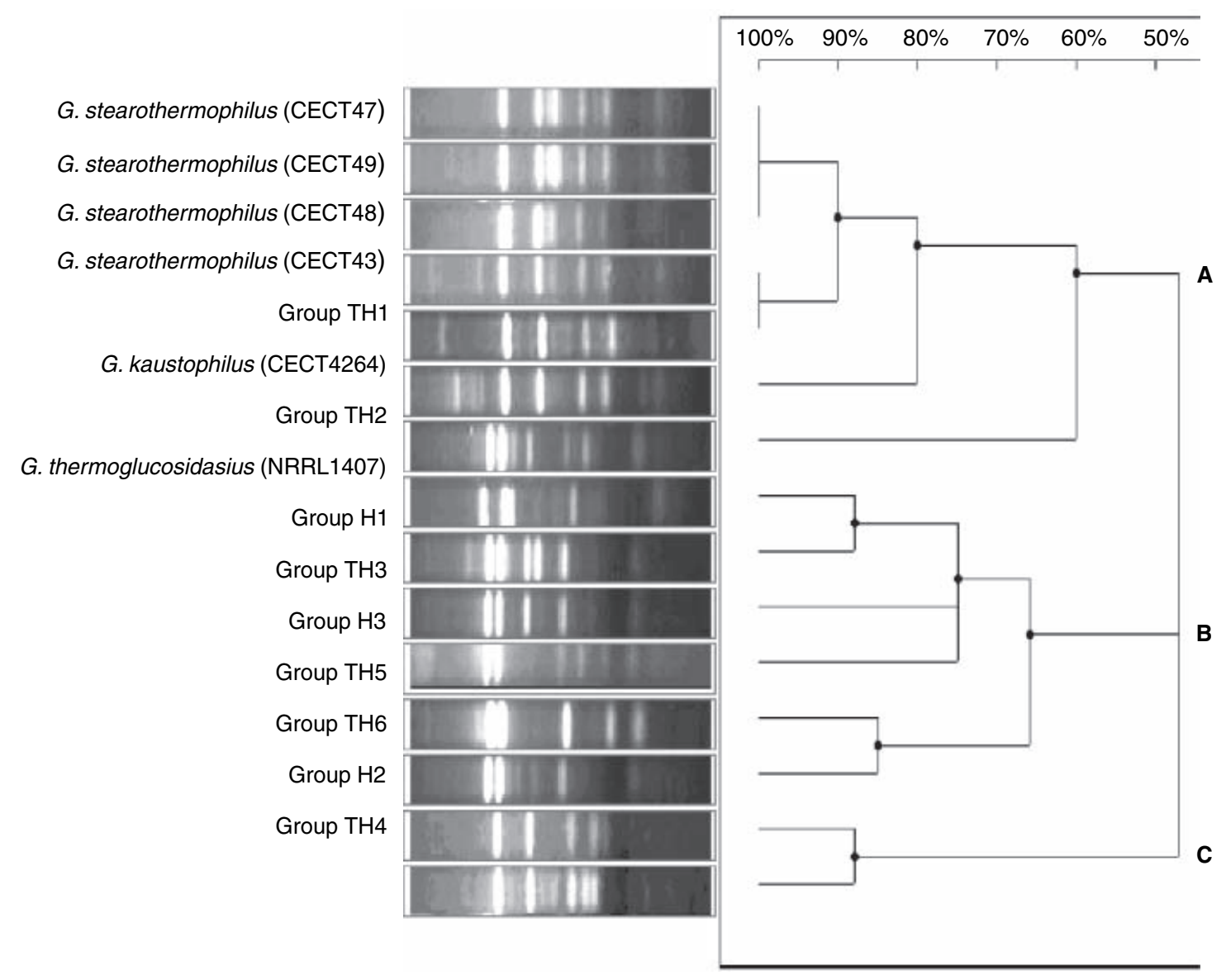

Fig. 2 Dendrogram showing the 16S-ITS rDNA RFLP homology groups obtained with HaeIII restriction enzyme. Restriction patterns of each of the homology groups were normalized against a DNA size marker (1 kb DNA ladder; Fermentas), and analysed with 15\% homology coefficient in a computer programme (Bio-1 D++; Vilber-Lourmat). The name of the homology groups and of reference strains were indicated (left). A, B and C indicate the three main clusters

two of the RFLP groups, T2 and T4, no significant sequence similarity was found in the nucleotide database.

\section{Plasmid profiling}

Plasmid DNA samples were digested with HaeIII restriction enzyme (Fig. 3). Two types of plasmid molecules were identified. One of the plasmids, p1, ca $12000 \mathrm{bp}$ in size, was contained in 13 of the strains which were dispersed into four homology groups (M24.p1 in TH1; M1A.p1, M2.p1, M5.p1, M6.p1, M9.p1, M33.p1, and V18.p1 in T1; M7.p1, M13.p1, and M20.p1 in T2; M1.p1 and M3.p1 in T3; Table 1). The other plasmid, p2 (Fig. 3), was much larger, ca $33000 \mathrm{bp}$, and found in two of the isolates (M32.p2 from group TH2, and V10.p2 from group TH5; Table 1). Reference strains did not contain any small plasmid DNA molecule. Thus it was clear that almost $50 \%$ of the isolates from mud and only one isolate from hydrothermal vent samples contained a small plasmid
DNA while no small plasmid was found in the isolates of re-injection water.

\section{DISCUSSION}

Environmental strains of thermophilic bacilli from Balcova geothermal site were isolated and characterized on the basis of growth at different physiological conditions, extracellular enzyme production, plasmid DNA content, 16S-ITS RFLP pattern and 16S rRNA gene partial sequence analysis.

The sequencing results indicated the presence of three main groups within the 109 isolated strains: (i) including $64 \%$ of the RFLP groups (TH2, TH3, TH5, TH6, T1, T3, T5, H1 and H3; Table 1) that appeared to be similar to $A$. flavithermus; (ii) 14\% of the RFLP groups (TH1 and $\mathrm{H} 2$ ) to G. thermoleovorans; and (iii) $\mathrm{TH} 4$, showing the closest similarity to G. subterraneus. Consistent with the sequencing results the first and second main group members were 


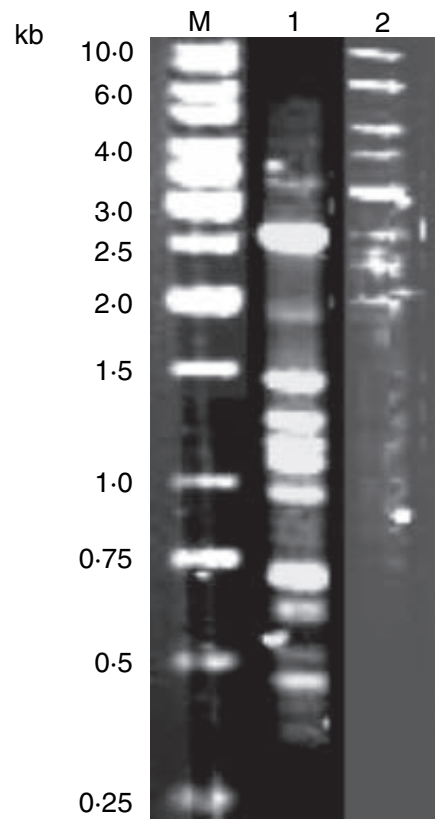

Fig. 3 Plasmid profiles with HaeIII restriction enzyme. Lane 1, p1 plasmid; lane 2, p2 plasmids; M, 1 kb DNA ladder (GeneRuler; Fermentas)

located into distinct clusters in the Taq $\mathrm{I}$ dendrogram (Fig. 1; B and A, respectively). Furthermore, HaeIII dendrogram appeared to locate each of these groups into three distinct clusters (Fig. 2; A, G. thermoleovorans; B, A. flavithermus, and C, G. subterraneus). In this dendrogram TH4 seemed to be closely related (87\%) to $\mathrm{H} 2$.

Anoxybacillus flavithermus has been described to grow in $2.5 \% \mathrm{NaCl}$ but not in $3 \% \mathrm{NaCl}$, and at $\mathrm{pH}$ from 6 to 9 (Pikuta et al. 2000). Some members of the homology groups showing 16S RNA gene similarity to A. flavithermus, however, grew at $3 \% \mathrm{NaCl}$ concentration and at $\mathrm{pH} 10$ (Table 1). Furthermore, environmental strains which have $<97 \% 16$ S rRNA gene sequence similarity in the same genus, have been considered as members of different species (Belduz et al. 2003). None of the RFLP homology groups, however, displayed sequence similarity above $94 \%$. These data could suggest that the isolates might represent different species than A. flavithermus. Geobacillus thermoleovorans has been described as obligately thermophilic $\left(45-70^{\circ} \mathrm{C}\right)$ with optimum $\mathrm{pH}$ ranging from $6 \cdot 2$ to $7 \cdot 5$ (Zarilla and Perry 1987). The homology group $\mathrm{H} 2$ included isolates which grew at $37^{\circ} \mathrm{C}$ and at $\mathrm{pH} 9$ (Table 1). Thus the isolates contained within this homology group might represent different species than G. thermoleovorans. The isolates included in TH1 produced identical RFLP patterns with G. stearothermophilus (CECT 43) and they could be the environmental strains of $G$. stearothermophilus. Besides the $91 \%$ 16S rRNA gene sequence similarity, examined phenotypic features of the isolate R76 of TH4 (Table 1) were also found to be similar to those of G. subterraneus (Nazina et al. 2001).

So far many attempts have been made to screen thermophilic and alcalophilic bacteria from natural sources (Bataillon et al. 1998; Horikoshi 1999; Mamo and Gessesse 1999; Niehaus et al. 1999; Haki and Rakshit 2003). The use of enzymes stable at high $\mathrm{pH}$ and temperature especially contribute to technical and economical feasibilities of hydrolysis process (Yu et al. 1987; Mamo and Gessesse 1999).

Majority of the isolates showed lipolytic and amylolytic activities (Table 1). Microbial lipases have been used as important biocatalysts in biomedical applications. Because of their excellent catalytic performance in a variety of organic solvents, they could be used for the synthesis of compounds of pharmaceutical interest. Lipases are also used for transesterification and for racemization reactions to produce optically pure enantiomers (Muralidhar et al. 2002). Such kinetic resolution processes are very important for example in the preparation of nonsteroidal anti-inflammatory drugs, anti-tumour agents, alkaloids, antibiotics and vitamins (Pandey et al. 1999). Microbial amylases might also be used in pharmaceutical industry. A maltogenic amylase of G. stearothermophilus, for example, could trans-glycosylate erythritol, a four-carbon sugar alcohol, and thereby change its physicochemical and sensory properties (Pandey et al. 2000). In the present study all the isolates displayed at least one enzyme activity and most of them (except 12 isolates) were able to grow at $\mathrm{pH} 10$. Thus it might be suggested that these strains may be good sources of novel industrial enzymes.

The isolated strains were differentiated into 14 distinct homology groups by the analysis of 16S-ITS rDNA RFLP results. This method has been used for the molecular identification of lactobacilli (Yavuz et al. 2004) and alkalophilic Bacillus (Akbalik et al. 2004). These reports and the present work demonstrated that 16S-ITS rDNA RFLP could be a useful molecular characterization tool for the rapid identification of environmental bacterial strains of diverse origin.

\section{REFERENCES}

Adams, M.W.W. and Kelly, R.M. (1998) Finding and using hyperthermophilic enzymes. Trends in Biotechnology 16, 329-332.

Aguilar, A., Ingemansson, T. and Magnien, E. (1998) Extremophile microorganisms as cell factories: support from the European Union. Extremophiles 2, 367-373.

Akbalik, G., Gunes, H., Yavuz, E., Yasa, I., Harsa, S., Elmaci, Z.S. and Yenidunya, A.F. (2004) Identification of extracellular enzyme producing alkalophilic bacilli from Izmir province by 16S-ITS rDNA RFLP. Fournal of Applied Microbiology doi:10.1111/j. 1365-2672.2004.02357.x

Ausubel, F.M., Brent, R., Kingston, R.E., Moore, D.D., Seidman, J.G., Smith, J.A. and Struhl, K. (1994) Current Protocols in Molecular Biology 3, Chapter 2. John Wiley \& Sons, Inc., New York. 
Bataillon, M., Cardinali, A.P.N. and Duchiron, F. (1998) Production of xylanases from a newly isolated alkalophilic thermophilic Bacillus sp. Biotechnology Letters 20, 1067-1071.

Belduz, A.O., Dulger, S. and Demirbag, Z. (2003) Anoxybacillus gonensis sp. nov., a moderately thermophilic, xylose-utilizing, endospore-forming bacterium. International Fournal of Systematic and Evolutionary Microbiology 53, 1315-1320.

Bragger, J.M., Daniel, R.M., Coolbear, T. and Morgan, H.W. (1989) Very stable enzymes from extremely thermophilic archaebacteria and eubacteria. Applied Microbiology and Biotechnology 31, 556-561.

Demirjian, D., Moris Varas, F. and Cassidy, C.S. (2001) Enzymes from Extremophiles. Current Opinions in Chemical Biology 5, 144 151.

Flint, S.H., Ward, L.J.H. and Walker, K.M.R. (2001) Functional grouping of thermophilic bacillus strains using amplification profiles of the 16-23S internal spacer region. Systematic and Applied Microbiology 24, 539-548.

Goto, K., Omura, T., Hara, Y. and Sadale, Y. (2000) Application of partial 16S rDNA sequence as an index for rapid identification of species in the genus Bacillus. Fournal of General Applied Microbiology $46,1-8$.

Haba, E., Bresco, O., Ferrer, C., Marques, A., Basquets, M. and Manresa, A. (2000) Isolation of lipase secreting bacteria by deploying used frying oil as selective substrate. Enzyme and Microbial Technology 26, 40-44.

Haki, G.D. and Rakshit, S.K. (2003) Developments in industrially important thermostable enzymes: a review. Bioresource Technology 89, 17-34.

Holt, J.G. and Krieg, N.R. (1994) Enrichment and isolation. In Methods for General and Molecular Bacteriology ed. Gerhardt, P. pp. 197-200. American Society of Microbiology Publications, Baltimore, MA, USA.

Horikoshi, K. (1999) Alkaliphiles: some applications of their products for biotechnology. Microbiology and Molecular Biology Reviems 63, No. 4, 735-750.

Huges, R.A.P. and Williams, R.A.D. (1977) Yellow-pigmented strains of Thermus ssp. from Icelandic hot springs. Fournal of General Microbiology 102, 375-383.

Jensen, M.A., Webster, J.A. and Strauss, N. (1993) Rapid identification of bacteria on the basis of polymerase chain reaction-amplified ribosomal DNA spacer polymorphisms. Applied and Environmental Microbiology 59, 943-952.

Kobayashi, T., Hatada, Y., Higaki, N., Lusterio, D.D., Ozawa, T., Koike, K., Kawai, S. and Ito, S. (1999) Enzymatic properties and deduced amino acid sequence of a high alkaline pectate lyase from an alkaliphilic Bacillus isolate. Biochimica et Biophysica Acta 1427, 145154.

Kristjansson, J.K. (1989) Thermophilic organisms as sources of thermostable enzymes. Trends in Biotechnology 7, 349-353.

Mamo, G. and Gessesse, A. (1999) Purification and characterisation of two raw-starch-digesting thermostable amylases from a thermophilic Bacillus. Enzyme and Microbial Technology 25, 433-438.

Marteinsson, V.T., Birrien, J.L., Jeanthon, C. and Prieur, D. (1996) Numerical taxonomic study of thermophilic Bacillus isolated from three geographically separated deep-sea hydrothermal vents. FEMS Microbiology Ecology 21, 255-266.

Maugeri, T.L., Gugliandolo, C., Caccamo, D. and Stackebrandt, E. (2001) A polyphasic taxonomic study of thermophilic bacilli from shallow, marine vents. Systematic and Applied Microbiology 24, 572 587.

Muralidhar, R.V., Chirumamilla, R.R., Marchant, R., Ramachandran, V.N., Ward, O.P. and Nigam, P. (2002) Understanding lipase stereoselectivity. World Fournal of Microbiology and Biotechnology 18, 81-97.

Nazina, T.N., Taurova, T.P., Poltaraus, A.B., Novikova, E.V., Grigoryan, A.A., Ivanova, A.E., Lysenko, A.M., Petrunyaka, V.V. et al. (2001) Taxonomic study of aerobic thermophilic bacilli: descriptions of Geobacillus subterraneus gen. nov., sp. nov. and Geobacillus uzenensis sp. nov. from petroleum reservoirs and transfer of Bacillus stearothermophilus, Bacillus thermocatenulatus, Bacillus thermoleovorans, Bacillus kaustophilus, Bacillus thermoglucosidasius and Bacillus thermodenitrificans to Geobacillus as the new combinations G. stearothermophilus, G. thermocatenulatus, G. thermoleovorans, G. kaustophilus, G. thermoglucosidasius and $G$. thermodenitrificans. International fournal of Systematic and Evolutionary Microbiology 51, 433-446.

Niehaus, F., Bertoldo, C., Kahler, M. and Antranikian, G. (1999) Extromophiles as a source of novel enzymes for industrial application. Applied Microbial Biotechnology 51, 711-729.

Pandey, A., Benjamin, S., Soccol, C.R., Nigam, P., Krieger, N. and Soccol, V.T. (1999) The realm of microbial lipases in biotechnology. Biotechnology and Applied Biochemistry 29, 119-131.

Pandey, A., Nigam, P., Soccol, C.R., Soccol, V.T., Singh, D. and Mohan, R. (2000) Advances in microbial amylases. Biotechnology and Applied Biochemistry 31, 135-152.

Pikuta, E., Lysenko, A., Chuvilskaya, N., Mendrock, U., Hippe, H., Suzina, N., Nikitin, D., Osipov, G. et al. (2000) Anoxybacillus pushchinensis gen. nov., sp. nov., a novel anaerobic, alkaliphilic, moderately thermophilic bacterium from mature, and description of Anoxybacillus flavithermus comb.nov. International Fournal of Systematic and Evolutionary Microbiology 50, 2109-2117.

Pikuta, E., Cleland, D. and Tang, J. (2003) Aerobic growth of Anoxybacillus pushchinoensis $\mathrm{K}^{{ }^{\mathrm{T}}}$ : emended descriptions of $A$. pushchinoensis and the genus Anoxybacillus. International Fournal of Systematic and Evolutionary Microbiology 53, 1561-1562.

Priest, G.F., Goodfellow, M. and Todd, C. (1988) A numerical classification of the genus Bacillus. Fournal of General Microbiology 134, 1847-1882.

Rainey, F.A., Fritze, D. and Stackebrandt, E. (1994) The phylogenetic diversity of thermophilic members of the genus Bacillus as revealed by 16S rDNA analysis. FEMS Microbiology Letters 115, 205-212.

Slepecky, R.A. and Hemphill, H.E. (1991) In The genus BacillusNonmedical. The Prokaryotes, 2nd edn ed. Ballows, A. pp. 16631696. New York: Springer Verlag.

Sullivan, D.O. and Klaenhammer, T. (1993) Rapid miniprep isolation of high quality plasmid DNA from Lactococcus and Lactobacillus spp. Applied and Environmental Microbiology 59, 2730-2733.

Yavuz, E., Gunes, H., Bulut, C., Harsa, S. and Yenidunya, A.F. (2004) RFLP of 16S rDNA-ITS region to differentiate Lactobacilli at species level. World Fournal of Microbiology and Biotechnology (in press).

Yu, E.K.C., Tan, L.U.L., Chan, M.K.H., Deschatelets, L. and Saddler, J.N. (1987) Production of thermostable xylanase by a thermophilic fungus, Thermoascus aurantiacus. Enzyme and Microbial Technology 9, 16-24.

Zarilla, A.K. and Perry, J.J. (1987) Bacillus thermoleovorans, sp. nov., a species of obligately thermophilic hydrocarbon utilizing endosporeforming bacteria. Systematic and Applied Microbiology 9, 258-264. 